\title{
Ilmu Hukum Sebagai Keilmuan Perspektif Paradigma Holistik
}

\author{
Arief Budiono \\ Universitas Muhammadiyah Ponorogo \\ Jl. Budi Utomo No. 10 Ponorogo \\ areevahims@gmail.com \\ Wafda Vivid Izziyana \\ Universitas Muhammadiyah Ponorogo \\ Jl. Budi Utomo No. 10 Ponorogo \\ wafda.vivid@yahoo.com
}

\begin{abstract}
The thought of law science today is getting stagnant and being doubtful because it tends to be mainstream positivistic. Positivism paradigm is a rigid paradigm, autonomous, and the law becomes merely a law that reduces the law itself to be simple, linear, mechanistic and deterministic then it raises the condition that positive justice is a procedural justice and not an essential justice. The positivist concept produces an incomplete legal study and then it is being dry, stiff and unable to explain the reality. Such of this condition causes an anxiety then the law science requires a shift paradigm so that there is no gap between Das Sein and Das Sollen. Therefore, the holistic paradigm has become the choice for legal science to be genuine science and signifies that the real science of law is not static but dynamic. This paradigm is an effort to formulate the science of law as a unity of science which is full of values and philosophy to reveal truth and justice to the level of meaning.
\end{abstract}

Keywords: Law Science; Holistic Paradigm; Positivism

\begin{abstract}
Abstrak
Pemikiran hukum saat ini mengalami stagnan dan menjadi diragukan karena kecenderungannya sebagai mainstream positivistik yang mainstream. Paradigma positivis adalah paradigma yang rigid dan untuk itu hukum hanya menjadi hukum yang mengurangi nilai dari hukum yang simpel, linier, mekanistik, deterministik, di mana selanjutnya menumbuhkan kesan bahwa keadilan positif merupakan keadilan prosedural, bukannya keadilan secara esensinya. Konsep positifistik menghasilkan kajian hukum yang kurang sempurna sehingga ia kurang memberikan penjelasan dari sisi realita. Kondisi ini mengakibatkan kegelisahan yang kemudian mendorong terjadinya pergeseran paradigma terhadap ilmu hukum, sehingga tidak ada gap antara Das Sein dan Das Sollen. Oleh karenanya, paradigma holistic dapat menjadi alternatif dalam ilmu hukum agar dapat menjadi ilmu yang asli dan signifikan dengan realitas ilmu yang menunjukkan bahwa hukum itu tidak statis, namun dinamis. Paradigma ini dapat menjadi usaha untuk memformulasikan ilmu hukum sebagai kesatuan ilmu yang penuh dengan nilai dan filosofi untuk menampilkan kebenaran dan keadilan di tingkat pemaknaan yang lebih riil.
\end{abstract}

Kata Kunci: Ilmu Hukum; Paradigma; Holistik 


\section{A. PENDAHULUAN}

Ilmu hukum selama ini di dalam perkembangannya, selalu diperdebatkan keabsahannya sebagai ilmu ataukah bukan, oleh ilmuwan bidang sosial maupun ilmuwan yang berperan di bidang hukum sendiri. Sudah sejak lama pertanyaan tersebut timbul dan harus dijawab secara akademis, apakah Ilmu Hukum merupakan ilmu? Menurut Lasiyo, pertanyaan tersebut harusnya tidak sekedar dicari jawabannya secara instan, tetapi juga harus dikaji dan dianalisis berdasarkan landasan pijak yang kuat dan jelas dari aspek keilmuan (Lasiyo, 2003: 3)

Mengikuti tradisi jurisprudence, ilmu hukum sebagaimana yang diajarkan di fakultas-fakultas hukum di Indonesia tidak masuk kategori dalam alur sains, sebagai legal science (Dimyati, 2015: 1) Selama ini ilmu hukum dikenal secara mainstream memiliki karakter yang khas, yaitu karakter yang normatif, praktis, dan positivistik. Menurut Philipus M. Hadjon bahwa karakter yang demikian menyebabkan sementara pihak yang memahami karakteristik ilmu hukum itu mulai meragukan hakekat keilmuan hukum. Keraguan tersebut dikarenakan karena kajian terhadap ilmu hukum lebih bersifat normatif ketimbang empiris (Djatmiati \& Hadjon, 2005: 1).

Istilah ilmu (science) menyandang dua makna, yaitu sebagai produk dan sebagai proses. Sebagai produk, ilmu adalah pengetahuan yang sudah terkaji kebenarannya dalam bidang tertentu dan tersusun dalam suatu sistem. Wim van Dooren, mengemukakan bahwa ilmu dapat didefinisikan sebagai pengetahuan yang sah secara intersubyektif dalam bidang kenyataan tertentu yang bertumpu pada satu atau lebih titik tolak dan ditata secara sistematis (Sidharta, 1999: 104).

Sebagai proses, istilah ilmu menunjuk pada kegiatan akal budi manusia untuk memperoleh pengetahuan dalam bidang tertentu secara bertatanan (stelselmatig) atau sistematis dengan menggunakan seperangkat pengertian yang secara khusus diciptakan untuk itu, untuk mengamati dan mengamati gejala-gejala (gegevens) yang relevan pada bidang tersebut, yang hasilnya berupa putusan-putusan yang keberlakuannya terbuka untuk dikaji oleh orang lain berdasarkan kriteria yang sama dan sudah disepakati atau yang dilazimkan dalam lingkungan komunitas keahlian dalam bidang yang bersangkutan.

Keraguan terhadap ilmu hukum sebagai sebuah ilmu mengemuka pada abad 19. Muncul pandangan yang meragukan posisi keilmiahan dari ilmu hukum, yaitu J.H. Von Kirchmann pada tahun 1848 dalam sebuah pidatonya yang diberi judul "Die Wertlosigkeit der Jurisprudenz als Wissenschaft (Ketidakberhargaan Ilmu Hukum Sebagai Ilmu)", inti pidato tersebut menyatakan bahwa ilmu hukum itu bukan ilmu. Pada abad 20 sekitar tahun 1932, A.V. Lundstedt dalam karyanya yang berjudul "Die Inwissenschaftl ichkeit der Rechtswissenshaft (Ketidak Ilmiahan Ilmu Hukum)”, juga menyebutkan bahwa ilmu hukum bukan merupakan ilmu yang ilmiah. J.H. von Kirchmann berpendapat bahwa obyek studi dari apa yang dinamakan Ilmu Hukum itu adalah hukum positif yang hidup dan berlaku dalam suatu masyarakat. 
Begitu Ilmu Hukum selesai memaparkan sistem hukum positif yang berlaku dalam masyarakat, maka hasil pemaparannya itu akan tertinggal oleh dinamika hukum positif itu sendiri. Hal ini disebabkan oleh karena hakikat dari sistem hukum positif itu yang selalu bergerak dinamis dan berubah-ubah mengikuti dinamika kebutuhan masyarakat. Penolakan kedua tokoh ini terhadap ilmu hukum berdiri di atas argumentasi bahwa objek dari ilmu hukum itu tidak seperti ilmu lainnya yang memiliki sifat universal-bersifat lokal. Objek ilmu hukum tidak dapat dipegang karena selalu berubah dan berbeda dari waktu ke waktu dan dari tempat ke tempat, intinya ilmu hukum tidak memiliki landasan keilmuan sebagaimana yang dimiliki oleh ilmu lain (Faisal, 2010: 1).

Di sisi lain, Paul Scholten melalui karyanya berjudul "De Structuur der Rechtswetenschap" tahun 1942 yang dikutip oleh Anis mencoba menjernihkan tentang status ilmu hukum sebagai ilmu yang sesungguhnya. Dalam karyanya tersebut, Scholten secara ringkas, jernih, dan jelas memaparkan pandangannya tentang hukum, keadilan dan ilmu hukum (Ibrahim, 2007: 8-9).

Perdebatan apakah hukum merupakan sebuah ilmu mengemuka tentu bukan tanpa suatu alasan dan ini merupakan hal yang sangat penting untuk dicermati dan diperhatikan oleh ilmuwan ilmuwan yang berkecimpung atau memiliki kepedulian terhadap ilmu hukum., Ilmu Hukum masih menjadi perdebatan dan mengalami perkembangan untuk mengukuhkan diri menjadi ilmu yang sebenar ilmu.

Salah satu masalah yang masih dihadapi oleh ilmu hukum terkait dengan hakikat pengetahuan apa yang dikaji (ontologis), bagaimana cara untuk mengeksplorasi suatu pengetahuan yang benar (epistemologis), dan untuk apa pengetahuan dipergunakan (aksiologis). Pada dasarnya semua pengetahuan apakah ilmu, seni, atau pengetahuan yang lain mempunyai ketiga landasan tersebut. Bedanya adalah materi perwujudannya serta sejauh mana landasan-landasan dari tiga landasan tersebut dikembangkan dan dilaksanakan (Suriasumantri, 2005: 35).

Keragu-raguan bahwa ilmu hukum sebagai sebuah ilmu tidak dapat dilepaskan dari realitas ilmu hukum yang masih berkutat dan berpegang teguh pada mainstream positivistik sehingga ilmu hukum menjadi sepi dan gersang tanpa dialektik ditengah hiruk pikuknya perkembangan ilmu pengetahuan. Hukum yang bersifat formal, yang di negara-negara penganut civil law dihimpun sebagai yurisprudensi, dan di negara-negara penganut common law dihimpun dalam wujud judge made law.

Sampai saat ini corak jurisprudence Indonesia yang berkutat pada mainstream positivistik merupakan warisan atau akibat dari penjajahan Belanda. Sementara dari segi perspektif keilmuan, ilmu hukum yang positivistik dengan metode analisisnya sangat kesulitan dalam memberikan eksplanasi karena ilmu hukum tereduksi menjadi jenis pengetahuan yang memiliki objek kajian hanya kasus-kasus tertentu saja dan semuanya diselesaikan hanya dengan teks-teks peraturan belaka dan penafsirannya amat pragmatik demi memecahkan kasus belaka. 
Sementara secara teoritik, corak positivistik berfungsi sebagai sumber hukum yang bersifat materiil berupa asas-asas. Dalam tradisi jurisprudence seperti di narasikan di atas, ilmu hukum lebih tampak sebagai suatu state of the art atau seni berfikir khusus. Artinya, lebih berorientasi untuk menemukan aturan-aturan yang dapat diterapkan in concreto dari sistem peraturan-peraturan positif yang telah disusun secara logis, koheren dalam jenjang hirarkhis. Dalam ilmu hukum yang legalistis-positivistis hukum sebagai institusi pengaturan yang kompleks telah direduksi menjadi sesuatu yang sederhana, linier mekanistik dan deterministik, terutama untuk kepentingan profesi dan menimbulkan "the great lacuna" atau "kekosongan besar" atas discourse ilmu hukum memiliki implikasi atas lambannya perkembangan ilmu hukum di Indonesia (Dimyati, 2015: 1-2)

Masalah yang timbul adalah sifat dari hukum itu sendiri. Sebagai perbandingan, objek formal dari fisika adalah atom atau sub-atomik, jiwa sebagai objek formal dari psikologi. Objek-objek tersebut dijelaskan menurut paradigma kausalitas, akan tetapi objek ilmu hukum yang positivis adalah hukum positif tidak dapat dijelaskan secara kausalitas. Hakikat hukum itu adalah standar atau patokan (Soekanto, 1986: 30) tentang apa yang seyogyanya harus dilakukan. Dengan alasan itu lalu timbul pandangan yang menyatakan hukum itu bersifat preskriptif. Sifat preskriptif dari hukum tidak dapat dijelaskan manurut paradigma kausalitasan, dan karena itu timbul pendapat bahwa karena objeknya bersifat preskriptif, tidak dapat dijelaskan melalui penjelasan kausal dan karena itu ia tidak dapat disebut ilmu (Syarifuddin \& Febriani, 2014: 2).

Konteks hukum Indonesia, doktrin dan ajaran hukum yang positivistik masih menjadi mainstream. Dikarenakan positivistik legisme melihat hukum hanya dari teleskop perundang-undangan belaka untuk kemudian menghakimi peristiwa empiris yang terjadi. Dalam konteks hukum yang positivistik ternyata dihadapkan pada fakta hukum yang memunculkan ketidakpaduan antara kajian teoritis dengan penerapan hukum positif tersebut.

Ketidakpaduan antara keadaan yang diharapkan (das sollen) dengan kenyataan (das sein) menimbulkan tanda tanya mengenai apa sebenarnya permasalahan hukum (problem hukum) dari segi normatif. Dengan demikian apa yang diharapkan terjadi akibat hukum tersebut ternyata tidak berfungsi seperti yang diharapkan atau justru menimbulkan konflik yang menyebabkan ketidakadilan, ketidaktertiban, dan ketidakpastian hukum dalam masyarakat dan ini bertentangan dengan cita cita hukum itu sendiri (Zaidah, 2003: 3).

\section{B. PEMBAHASAN}

Hukum sebagai sesuatu keilmuan menurut perspektif paradigma holistik telah disampaikan dan dibahas di antaranya oleh Satjipto Rahardjo yang merupakan salah satu pelopor paradigma holistik dalam ilmu hukum di mana ilmu hukum positif telah gagal untuk menyajikan gambar hukum yang lebih benar. Hal ini terbukti dengan munculnya berbagai disiplin yang mengisyaratkan bahwa obyek studi hukum itu 
tidaklah sesempit seperti difahami oleh para ilmuwan hukum di abad ke-sembilan belas. Kesalahan dalam memperoleh gambaran terhadap hukum yang lebih benar terletak pada pemahaman obyek studi yang dibatasi pada hukum perundangundangan.

Dalam studi hukum analitis yang mengawali ilmu hukum modern, orang hanya mendapat panduan dalam hal memahami dan mengoperasikan hukum positif. Padahal sebagai ilmu yang otentik, maka ilmu hukum dituntut untuk bisa memberikan dan menampilkan gambar yang lebih utuh tentang hukum. Misalnya psikologi modern telah gagal untuk menyajikan gambar tentang manusia secara utuh, karena hanya menampilkan gambar tentang kepingan-kepingan jiwa manusia. Untuk memperoleh gambaran yang utuh tentang hukum, maka kesalahan tersebut perlu diperbaiki, yaitu dengan mengaitkan dunia positif-normatif kepada dunia kehidupan nyata.

Metodologi analitis Cartesian, Baconian, dan Newtonian tidak membawa kita kepada pemahaman yang benar tentang alam dan kehidupan. Metodologi baru yang menggantikan harus mengutuhkan, bukan memisah-misahkan. Pendekatan demikian disebut dengan pendekatan dan metodologi holistik. Paradigma holistik akan mengubah peta berhukum dan pembelajaran hukum yang selama ini memandu kita (Rahardjo, 2005: i).

Hukum secara holistik memiliki ontologi hukum yaitu ilmu tentang segala sesuatu (merefleksi hakikat hukum dan konsep-konsep fundamental dalam hukum, seperti konsep demokrasi, hubungan hukum dan kekuasaan, hubungan hukum, dan moral). Aksiologi hukum yaitu ilmu tentang nilai (merefleksi isi dan nilai-nilai yang termuat dalam hukum seperti kelayakan, persamaan, keadilan, kebebasan, kebenaran, dan sebagainya). Ideologi hukum yaitu ilmu tentang tujuan hukum yang mengangkut cita manusia (merefleksi wawasan manusia dan masyarakat yang melandasi dan melegitimasi kaidah hukum, pranata hukum, sistem hukum dan bagian-bagian dari sistem hukum).

Teologi hukum yaitu ilmu tentang tujuan hukum yang menyangkut cita hukum itu sendiri (merefleksi makna dan tujuan hukum). Epistemologi yaitu ilmu tentang pengetahuan hukum (merefleksi sejauh mana pengetahuan tentang hakikat hukum dan masalah-masalah fundamental dalam filsafat hukum mungkin dijalankan akal budi manusia). Logika hukum yaitu ilmu tentang berpikir benar atau kebenaran berpikir (merefleksi aturan-aturan berpikir yuridik dan argumentasi yuridik, bangunan logical serta struktur sistem hukum) (http://duniahukumonline.blogspot.co.id/search, diakses pada tanggal 10 Januari 2017)

Menurut Khudzaifah Dimyati bahwa perspektif yang holistik dan serba multi, ilmuwan hukum harus berusaha mengembara di wilayah yang belum pernah disentuh ilmuwan lain. Teori kuantum dijadikan instrumen untuk meneropong ilmu 
hukum, yang memfokuskan pada undang-undang, legislatif, yudikatif, eksekutif, proses hukum, dan sebagainya. Dalam perspektif teori kuantum, semua adalah gelombang yang tampak dengan mudah dapat diamati dan dipelajari. Akan tetapi, sebenarnya substansi besar yang menjadi landasan dari hal-hal yang teramati tersebut tetap diam dibalik penampilan yang empirik itu. Substansi itulah yang disebut sebagai ketertiban, tetapi ketertiban juga bisa menampilkan sisi lain, yakni ketidaktertiban.

Paradigma holistik memiliki keyakinan bahwa agar terjadi kemajuan serta terangkatnya derajat ilmu hukum, maka perlu bagi ilmu hukum dan ilmuwannya untuk meminjam metode dari ilmu lain seperti Ilmu Fisika sebagai instrumen untuk memotret dan menjelaskan lebih mendalam fenomena-fenomena hukum yang berupa riak-riak dangelombang yang teramati sekaligus makna di balik gejala-gejala itu. Semangat yang kuat untuk memajukan ilmu hukum menjadi sebenar ilmu, membuat ilmuwan hukum harus bertualang memasuki lorong-lorong ilmu lain sebagai bahan rujukan petualangan intelektualnya (Dimyati, 2015: 4-5).

Karakter mainstream hukum positivis adalah sifatnya yang rasional yang diwujudkan dalam sifat peraturan hukum yang prosedural. Hal ini bahwa tujuan hukum untuk mencapai keadilan sudah tercapai dengan membuat hukum positif sesuai undang-undang, dan dengan demikian tujuan keadilan sudah tercapai dan cenderung otonom dan sulit menyelesaikan persoalan masyarakat yang berkembang sesuai dengan perkembangan masyarakat yang dinamis tidak dapat diwadahi oleh hukum yang positivis (Anita, 2016: 8).

Sisi lain dari positivistik hukum adalah tidak mempertimbangkan apakah keadilan yang dituju, apakah keadilan prodedural saja ataukah hukum efektif dipatuhi diberlakukan. Dalam hal ini Andreas Philippoulos dan Thomas E Webb mengutip Richard Nobles dan David Schiff bahwa (Philippopoulos-Mihalopoulos \& Webb, 2015: 381):

"explore the tension created between the legal and political systems, experienced through their structural coupling of politically permitted, but legally incomprehensible disobedience to law under certain conditions. They argue that, while civil incomprehensible, disobedience to law under certain conditions. They argue that, while civil disobedience has traditionally been accommodated by society" Bahwa ternyata peraturan secara substansi di buat oleh orang orang yang secara politik diterima tetapi tidak kompeten dalam menyusun hukum.

Asumsi paradigma positivis bahwa hukum suatu yang otonom dan sama sekali terbebas dari interest dan berorientasi pada aturan mendapat sanggahan dari Naomi Creutzfeldt, Agnieszka Kubal, dan Fernanda Pirie (2016: 385):

"Can we see that similar laws and legal practices reflect similar cultural beliefs and practices, Should we look to political, social, historical, economic or other factors to 
explain similarity? Similarities amongst legal phenomena across social and cultural divides has maybe not been sufficiently emphasised in the law"

bahwa hukum hukum dan praktiknya seharusnya merefleksikan kultur dan kepercayaan dan kenyataan dalam masyarakat dalam politik, sosial, ekonomi dan faktor lain.

Teori merupakan seperangkat konsep, batasan, serta proposisi yang menyajikan pandangan sistematis tentang fenomena dengan memperinci hubungan antar variabel dengan tujuan menjelaskan serta memprediksi suatu gejala permasalahan hukum (FN, 1996: 10-11). Maka teori-teori yang dipakai ialah yang berkaitan dengan teori hukum. Teori hukum adalah teori-teori atau pemikiran-pemikiran dalam perkembangan hukum (algamene rechtslehre/general jurisprudence) yang menekankan prinsip-prinsip hukum, teori hukum, ajaran hukum yang berupaya menempatkan posisi antara filsafat hukum dengan ilmu hukum (Manullang, 2007: 15).

Teori merupakan sebuah keberadaan yang sangat penting dalam dunia hukum. Hal tersebut karena teori merupakan konsep dasar yang dapat menjawab suatu masalah. Teori juga merupakan sarana yang memberikan rangkuman bagaimana memahami suatu masalah dalam setiap bidang ilmu pengetahuan hukum. Penting untuk seorang akademisi hukum mengetahui pengertian teori secara luas, sehingga tidak terjadi kesalahan dalam membuat karya-karya ilmiah yang merupakan proses kegiatan seorang akademisi dalam kegiatan ilmiah (Ishaq, 2008: 192).

Dalam karya ini diketengahkan tentang bagaimanakah agar hukum menjadi ilmu yang sebenarnya (genuine science) melalui paradigma yang holistik agar hukum juga mampu menjawab aspirasi dan kebutuhan sosial serta mampu mencerahkan hukum Hukum dapat mencapai kematangan menjadi sebenar ilmu dengan melihat kenyataan realitas hukum masyarakat dalam "the totally of life" melalui paradigm holistik (Indah, 2007: 3).

Paradigma itu sendiri menurut Like Wilardjo merupakan "Ordering belief framework" yang merupakan suatu asumsi yang diyakini ilmuwan dan menentukan cara dia memandang gejala yang ditelaahnya (Wilardjo, 1990:78). Menurut Kuhn sebagai mana dikutip oleh George ritzer dan Douglas J Goodman maka penggunaan paradigm diejawantahkan sebagai pencapaian ilmiah yang konkrit, tempat professional dari berbagai konsep, dalil, teori, dan titik pandang bisa disarikan darinya. Perolehan Paradigma merupakan tanda kematangan dalam perkembangan sains manapun (Ritzer \& Goodman, 2003: a11-a12).

Dalam paradigm holistik dapat dikaitkan antara ilmu hukum dan filsafat sehinga dapat membantu kita menelusuri pengetahuan yang lebih utuh tentang hukum. Filsafat mempelajari masalah ini sedalam-dalam nya dan hasil kajiannya merupakan dasar bagi eksistensi ilmu. Ontologi membahas tentang apa yang ingin kita ketahui, seberapa jauh kita ingin tahu atau dengan kata lain bahwa suatu pengkajian tentang teori "ada". Epistemologis yakni teori ilmu pengetahuan untuk menjawab cara kita mendapat 
pengetahuan tentang obyek dan aksiologi adalah teori tentang nilai untuk menjawab kegunaan ilmu tersebut dan analisis kefilsafatan ditinjau dari ketiga hal tersebut membawa kita pada hakikat yang dalam hal ini hakikat hukum sebagai ilmu (Suriasumantri, 1991: 28).

Kaitan ilmu dengan aksiologis menjadikan ilmu tak terpisahkan dari etika atau nilai. Karena itu harus mampu membawa manusia keluar dari kebiadaban menuju kebijaksanaan dan hikmah. Inilah pula yang harus diperjuangkan dalam hukum karena hukum haruslah untuk manusia (Indah, 2007: 5). Ide tentang manusia menjadi ide sentral dalam hukum sehingga konsep tidak akan dapat dipahami hanya dengan reduksionis, mekanistis, linier, dan positivistik.

Pendekatan holistik terhadap hukum merupakan reaksi atas pemikiran hukum yang selama ini hanya dipahami untuk kelangsungan status quo perundang-undangan saja. Hukum dan manusia untuk hukum. Hukum bukan untuk manusia sehingga studi hukum menjadi pincang secara etimologis dan teralienasi dari dinamika.

Menurut Sidharta sebagaimana dikutip oleh Herman Bakir bahwa cara yang dipakai teori hukum di ruang kritik ideologikal sangat disupportasi oleh tradisi berpikir dan bermetode hasil integrasi teori hukum dengan temuan temuan yang dipresentasikan keseluruhan disiplin ilmu (Bakir, 2005: 46). Melalui dukungan temuan ilmu-ilmu lain dengan pemikiran yang holistik akan membawa hukum menjadi tercerahkan.

Demikian halnya dengan teori sosiologis ada dalam Ilmu Hukum dikarenakan ingin melihat hakikat hukum yang tidak terbatas pada teks normatif yang abstrak. Lebih jauh lagi, hukum ingin dilihat dalam segenap kompleksitasnya dalam interaksinya dengan alam realitas empirik sebagai medan tumbuh-kembangnya hukum tersebut. Apakah bunyi aturan hukum benar-benar berfungsi atau tidak berfungsi dalam realitas empirik. Hal tersebut tidak akan diketahui jika hanya melakukan pengamatan terhadap ajaran-ajaran atau rumusan-rumusan yang resmi dan formal yang selama ini justru mendominasi sebagai mainstream dan mengakibatkan hukum diragukan sebagai sebuah ilmu. Untuk itu dibutuhkan penggunaan sosiologi dalam Ilmu Hukum. Terdapat beberapa faktor yang mendorong perkembangan minat terhadap sosiologi hukum, yaitu: perubahan-perubahan yang terjadi di dalam hubungan-hubungan sosial (termasuk sudah perubahan fisik dan teknologis) ketidaksesuaian antara ideal (das sein) dan kenyataan (das sollen) (Rahardjo, 1976: 251)

Ranah pengkajian ilmu hukum dibedakan dalam domain assumption of professional dan assumption of science. Pertama, pengkajian hukum semata dari rules and logic dan mempertahankan status quo hukum positif. Untuk pengkajian tingkat assumption of scientific membawa hukum pada "genuine science" yang senantiasa mencari "the truth of law" sehingga ilmu hukum tidak stagnan dan kering, dan terus mengemuka sebagai ilmu. Hukum yang dimaknai sebagai tatanan holistik yang dinamis merupakan hal yang esensi dan ilmu hukum bukan hanya aturan dan logika semata tapi 
nyata sebagai ilmu (Johnson, 1994: 14-15) dalam karakter yang genuine science yang selalu berkembang. Ini berarti pemikiran holistik merupakan pencerahan untuk kritis, kreatif, divergen, dan mendekontruksi alur pikir yang sudah mainstream dalam arti positivistik

Orientasi di dalam melakukan sebuah karya ilmiah mengindikasikan adanya suatu kaitan yang erat antara pandangan falsafati seorang peneliti dengan metode yang dipilih dan digunakan dalam melakukan penelitian. Di sinilah problem metodologis daripada epistemologi ilmu hukum diperdebatkan. Pilihan terhadap satu dimensi akan memiliki konsekuensi-konsekuensi metodologi terhadap pilihan pendekatan yang akan digunakannya dalam merumuskan konklusi. Konsekuensi terburuknya ialah ketersesatan pikir, sehingga karya ilmiah akan kehilangan nilai ilmiahnya (Salim, 2013: ii) .

Pada ilmu, alamiah ataupun ilmu apapun, termasuk ilmu hukum, maka kelangsungan perkembangan suatu ilmu akan ditentukan pada unsur-unsur teori, metodologi, aktivitas, serta imajinasi sosial. Teori di sini dapat diartikan sebagai suatu sistem yang berisikan proposisi-proposisi yang telah diuji kebenarannya.

Apabila berpedoman pada sebuah teori, maka seorang akademisi akan dapat menjelaskan aneka macam gejala sosial yang dihadapinya walaupun hal ini tidak selalu berarti adanya pemecahan terhadap masalah yang dihadapi (Nazir, 1988: 42). Dari penjelasan ini dapat ditarik beberapa kesimpulan, mengenai peranan metodologi dalam penelitian serta pengembangan ilmu pengetahuan, yakni (Soekanto, 1986: 2)

1. Menambah kemampuan para akademisi untuk mengadakan atau melaksanakan penelitian secara lebih baik atau lebih lengkap.

2. Memberikan kemungkinan yang lebih besar, untuk meneliti hal-hal yang belem diketahui.

3. Memberikan kemungkinan yang lebih besar untuk melakukan penelitian interdisipliner.

4. Memberikan pedoman untuk mengorganisasikan serta mengintegrasikan pengetahuan mengenai masyarakat.

\section{KESIMPULAN}

Paradigma holistik memiliki maksud pengkajian hukum secara komprehensi dengan sifat filsafat yang menyeluruh, mendasar serta lintas ilmu pengetahuan akan digunakan untuk mengupas secara mendalam isu hukum (legal issue). Pendekatan melalui paradigma holistic ini meliputi kajian ontologis (ajaran tentang hakikat), aksiologis (ajaran tentang nilai) dan epistimologis (tentang metodologi) dari pemikiran hukum (Saptomo, 2009: 37).

Tiga dimensi dari ilmu hukum, yakni dogmatik ilmu hukum, teori maupun filsafat berinteraksi untuk mencari kebenaran yang akan ditampilkan di dalam ilmu hukum. Ketiga dimensi tersebut tidak an-sich ber interaksi sendiri namun juga terbuka, 
berkelindan dengan keilmuan lain sehingga hukum bukanlah keilmuan yang murni, sistemik namun abai terhadap keilmuan dan science.

Hukum sebagai sebuah ilmu menurut paradigm holistic tidak dapat berdiri sendiri secara independen namun hukum juga berinteraksi dengan ilmu ilmu lain dalam lingkup ilmu pengetahuan. Ilmu Hukum dan ilmu lain berkaidah saling menyapa, saling berinteraksi dan mengadopsi berbagai teori dan kemanfaatan yang berkembang pada keilmuan di bidang lain demi bertambahnya khazanah dari ilmu hukum sebagai sebuah keilmuan.

\section{DAFTAR PUSTAKA}

\section{A. Buku}

Bakir, Herman (2005). Kastil Teori Hukum. Jakarta: Indeks Kelompok Gramedia.

Hadjon, Philipus M. dan Djatmiati, Tatiek Sri (2005). Argumentasi Hukum. Yogyakarta: Gadjah Mada University Press.

Ibrahim, Anis (2007). Merekonstruksi Keilmuan Ilmu Hukum dan Hukum Milenium Ketiga, Malang: In-TRANS.

Ishaq (2008). Dasar-Dasar Ilmu Hukum. Jakarta: Sinar Grafika.

Lasiyo dalam M. Hadin Muhjad, dkk, (2003). Peran Filsafat Ilmu dalam Ilmu Hukum: Kajian Teoritis dan Praktis. Surabaya: Unesa University Press.

Manullang, EFM (2007). Menggapai Hukum Berkeadilan: Tinjauan Hukum Kodrat dan Antinomi Nilai. Jakarta: Penerbit Buku Kompas.

Nazir, Mohammad (1988). Metode Penelitian, Jakarta: Ghalia Indonesia.

Purbacaraka, Purnadi dan Soekanto, Soerjono (1985). Sendi-Sendi Ilmu Hukum dan Tata Hukum. Bandung: Alumni.

Ritzer, George \& Goodman, Douglas J (2003). Teori Sosiologi Modern. Jakarta: Kencana. S. Johnson, Alfin (1994). Sosiologi Hukum. Jakarta: Rineka Cipta.

Saptomo, Ade (2009). Pokok-pokok Metodologi Penelitian Hukum Empiris Murni, Jakarta: Trisakti.

Sidharta, Bernard Arief (2000). Refleksi Tentang Struktur Ilmu Hukum. Bandung: Mandar Maju.

Soekanto, Soerjono (1986). Pengantar Penelitian Hukum, Jakarta: Universitas Indonesia Press.

Suriasumantri (1991). Ilmu dalam Perspektif: Kumpulan karangan tentang hakekat ilmu. Jakarta: Obor Indonesia.

Suriasumantri, Jujun S. (2005). Filsafat Ilmu Sebuah Pengantar Populer. Jakarta: Pustaka Sinar Harapan.

Wilardjo, Like (1990). Realita dan Desiderata, Yogyakarta, Duta Wacana University. Zaidah, Indah (2003). Problema hukum dalam penelitian normatif. Bandung: Sinar Grafika. 


\section{B. Jurnal}

Christiani, Theresia Anita (2008). Studi Hukum Berdasarkan perkembangan paradigma pemikiran hukum menuju metode holistik. Jurnal hukum Pro Justisia, 26(4).

Creutzfeldt, Naomi; Kubal, Agnieszka and Pirie, Fernanda (2016). Introduction: exploring the comparative in sociolegal Studies. International Journal of Law In Context, 12(4), doi: S1744552316000173.

Dimyati, Khudzaifah (2015). Problem Epistimologis Ilmu Hukum: Dialektik Perubahan Paradigma. Makalah disajikan dalam seminar "Pengembangan Epistemologi Ilmu Hukum, Surakarta.

Faisal (2010). Paradigma Holistik Hukum Progresif. Jurnal Hukum Progresif, 6(2).

Indah, Maya (2007). Memanusiakan Manusia melalui ilmu hukum yang holistic. Jurnal Studi Pembangunan Interdisipliner, 19(3).

Philippopoulos, Andreas and E. Webb, Thomas (2015). Introduction: critical sociolegal engagements with systems thinking. International Journal of Law in Context, (11)4, doi: S1744552315000245

Rahardjo, Satjipto (1976). Sosiologi Hukum di Indonesia. Majalah Fakultas Hukum Universitas Diponegoro, 6(6).

Rahardjo, Satjipto (t.t.). Pendekatan Holistik Terhadap Hukum. Jurnal Hukum Progressif, 1(2).

Salim, Kahfi (2013). Epistemologi Ilmu Hukum: Studi Tentang Model Penalaran Dalam Penyusunan Tesis di Program Magister IImu Hukum UMS. Unpublished Thesis, Surakarta, Program Pasca Sarjana UMS.

Syarifuddin, Amir dan Febriani, Indah (t.t.). Apakah Ilmu Hukum Adalah Ilmu. Jurnal Opini Hukum, Palembang, FH Unsri.

C. Internet

http://duniahukumonline.blogspot.co.id/search 